Отримано: 28.11.2019 р.

Прорецензовано: 05.12.2019 p.

Прийнято до друку: 10.12.2019 р.

e-mail: natalia.konopka@oa.edu.ua

DOI: $10.25264 / 2409-6806-2019-29-75-87$
Конопка Н. Михайло Антонович як дослідник історії України. Наукові записки Національного університету «Острозька академія». Серія «Історичні науки». Острог, 2019. Вип. 29. С. 75-87.

\title{
Наталія Конопка
}

\section{МИХАЙЛО АНТОНОВИЧ ЯК ДОСЛІДНИК ІСТОРІЇ УКРАЇНИ}

Стаття присвячена аналізу життя та творчості видатного українського історика, представника відомого роду Антоновичів - Михайла Дмитровича Антоновича. Автором здійснена спроба на основі опублікованих джерел відтворити біографію вченого, простежсти умови та особливості становлення його наукових інтересів, визначити інтелектуальне коло дослідника, висвітлити працю в украӥнських наукових інституиіях закордоном, проаналізувати наукові здобутки.

Основна увага в дослідженні зосереджена на вивченні історичних та політичних поглядів автора на основі аналізу 4-томної «Історії Украӥни», що вийшла друком в Празі у 1941-1942 рр. Праия є певним синтезом поглядів та оиінки істориком визначних подій, явищ та процесів історії України. Оиінка істориком прочесу державотворення є відмінною від популярних ідей державницького напряму початку ХХ ст. та зводиться до ідеї, що держава має значення лише як одна з функиій національного життя, як орган забезпечення розвитку народу. Відзначається, що прочес зародження та формування національної ідеї пройшов в своїй еволючї кілька етапів - від часу Київської Русі до початку XX ст. та залежсав від різних суспільних верств (духовенства, козаків, аристократії, інтелігенції), які не спромоглися на ї̈ остаточне оформлення та популяризацію. Вчений виокремив умови та причини неспроможності витворення належної теоретично-політичної концепиії до початку XX cm. Колонізачійний рух, на думку дослідника, мав для України і позитивні, і негативні риси. 3 однієї сторони були освоєні величезні простори, а відтак зростала економічна потуга украйнських земель, а з іншої - колонізаційний рух на південний схід переніс иентральну вісь начіонального життя з лінії Київ - Львів на Донбас з його русифікованим, а здебільшого чужсим та прийшлим населенням, щзо було нездатне витворити національну ідею.

Доведено, щңо погляди дослідника на український історичний та політичний процес акумулювали різні історіографічні традичії та підходи, водночас будучи цілком винятковими та унікальними.

Ключові слова: Михайло Антонович, історія Украйни, історіографія, держсавотворення, національна ідея, національний інтерес, «модерний націоналізм», Б. Хмельницький, Т. Шевченко.

\section{Nataliia Konopka}

\section{MYKHAILO ANTONOVYCH, THE RESEARCHER OF UKRAINIAN HISTORY}

The paper encompasses the analysis of the life and works of a prominent Ukrainian historian and the member of the famous Ukrainian Antonovych dynasty, Mykhailo Dmytrovych Antonovych. Basing on the published sources, the author of the article endeavors to render the scholar's biography, overview the life conditions and peculiarities of his academic interest formation, define the intellectual circle of the historian, present his work in Ukrainian research institutions and abroad, as well as to analyze his academic achievements.

The main attention in the research is paid to the study of historical and political views of Antonovych, basing on his 4-volume work "History of Ukraine" published in Prague in 1941-1942. It is a synthesis of the author's views and evaluation of the prominent events, phenomena and processes in the history of Ukraine. The historian's appraisal of the state formation process differs from the ideas which were popular in the early $20^{\text {th }}$ century and comes down to the idea of the state's only value as one of the functions of the national life and as the body which can provide the nation's development.

It is noted that the process of formation and articulation of national idea consisted of several evolutionary phases (from Kyivan Rus to the early 20th century) and depended on various social classes (clergy, Cossacks, aristocracy, intelligentsia), who failed in completing its articulation and popularization. Antonovych has singled out the conditions and reasons of the inability to create a proper theoretical and political conception before $20^{\text {th }}$ 
century. The researcher considers the colonial movement to have both positive and negative features for Ukraine. On the one hand, vast areas of land were cultivated, therefore, increasing the economic strengths of Ukrainian territory. On the other hand, colonization of the south-eastern regions led to the shift of the central axis of the national life from the line Kyiv - Lviv to Donbass region with its russified population, which was majorly alien and of non-Ukrainian origin and thus unable to create the national idea.

The author of the paper proves that Antonovych's views on Ukrainian political and historical process have accumulated various historiographic traditions and approaches being at the same time quite exceptional and unique.

Key words: Mykhailo Antonovych, history of Ukraine, historiography, state formation, national idea, national interest, “modern nationalism”, B. Khmelnytskyi, T. Shevchenko.

Михайло Дмитрович Антонович, представник молодшої генерації українських істориків початку XX ст., науковий та життєвий потенціал якого був невблаганно знищений радянською тоталітарною машиною, займає, без перебільшення, одне з чільних місць у розвитку української науки. Незважаючи на відносно невелику доступну наукову спадщину вченого (сьогодні існує потреба створення бібліографії його творів) та нечисленні джерельні матеріали, зробимо спробу в загальних рисах розглянути його життєвий і науковий шлях.

Скупі біографічні відомості про працю та науковий доробок Михайла Антоновича подав у першому томі «Енциклопедії українознавства» за 1955 р. Володимир Кубійович [7, с. 51]. Коротку інформацію про М. Антоновича вміщено Олександром Оглоблином в «Ukrainian Historiography, 1917-1956» («Українська історіографія, 1917-1956») (1957 р.) [29, с. 424-425]. Детальніший та повніший життєпис історика у 2003 р. проф. Олексієм Ясем було вміщено в першому томі «Енциклопедії історії України» [28, с. 107-108]. Найдетальніша наукова біографія М. Антоновича була опублікована Таїсією Ківшар 2008 р. в часописі «Українська біографістика» [11, с. 137-153]. Авторкою вперше була введена в науковий обіг автобіографія вченого, що зберігалася в ЩДАВО України [11, с. 138], яка дала змогу уточнити біографічні дані та окремі аспекти його наукової діяльності й спадщини. Спомини про зустріч Я. Рудницького (чоловік сестри Михайла - Марини (домашнє ім'я Ляля)) з Михайлом Антоновичем опубліковано на сторінках журналу «Український історик» (1989, ч. 4) [20].

Спогадам про останні роки життя Михайла Антоновича на засланні присвячені розвідки В. Яременка [26; 27, с. 140-142] та В. Тимощука [21; 22, с. 142-144], а також спомини М. Барбона [9, с. 134136; 17] та ін. Співпраці Михайла Антоновича з Українським історично-філологічним товариством у Празі присвятив своє детальне дослідження А. Шаповал [25, с. 88-99]. Окремі згадки про історика містяться і в монографії цього ж автора, присвяченій Дмитру Антоновичу [24].

Цінним джерелом до вивчення ретроспективи життєвого та творчого шляху вченого є Архів Українського історичного товариства, зокрема Архів Марка Антоновича, де зберігаються унікальні та маловідомі матеріали, присвячені родині Антоновичів, в тому числі листування, особові документи, рукописи праць Михайла Антоновича тощо [8].

Важливим джерелом є епістолярна спадщина. Зокрема, У. Великопольська у 2008 р. опублікувала три з сімох листів Михайла Антоновича до відомого вченого, публіциста, письменника та історика проф. Мирона Кордуби, написані у 1943 р. [10]. Окрім цього, унікальним та цінним джерелом до висвітлення інтелектуального кола та творчих прагнень молодого вченого є неопубліковані листи Михайла Антоновича до Олександра Оглоблина, що зберігаються в Архіві УІТ (Архів Марка Антоновича) [16]. Ці матеріали дають змогу окреслити особливості встановлення наукових інтересів молодого науковця, характер відносин між двома вченими, висвітлити обставини та невідомі факти життєвого шляху і наукової діяльності.

Народився Михайло Дмитрович Антонович 22 серпня 1909 р. у Флоренції ${ }^{1}$ (Італія) [28, с. 107-108] в родині відомих представників династії Антоновичів - Дмитра та Катерини. Початкову освіту здобув у Другій Державній гімназії ім. Кирило-Мефодіївського братства у Києві. У 1919 р., як відзначає А. Шаповал, він навчався у приватній французькій гімназії М. Мереслі, а з осені 1920 р. - у єдиній трудовій школі № 57 ім. І. Франка [25, с. 88-89].

Протягом 1924-1927 рр. навчався в українській гімназії в Празі [11, с. 138], де також проживала його родина. А у 1927/28 рр. вступив до Українського вільного університету в Празі, водночас сту-

\footnotetext{
${ }^{1}$ У своїх споминах М. Барбон помилився, стверджуючи, що М.Д. Антонович народився в Києві в будинку свого діда Володимира Боніфатійовича Антоновича на розі вулиць Кузнєчної та Жилянської.
} 
діюючи і в Університеті Фрідріха Вільгельма в Берліні. Від 1930 до 1933 рр. - завершив навчання у двох університетах, склавши докторські іспити.

Про активну наукову, громадську та благодійну діяльність Михайла Дмитровича згадував Симон Наріжний у своїй праці «Українська еміграція. Культурна праця української еміграції між двома світовими війнами», до видання якої долучилася і родина Антоновичів, зокрема Михайло. Окрім того, у слові «Від автора» С. Наріжний дякував М. Антоновичеві за перегляд окремих розділів, за фахові вказівки та надані матеріали [18, с. 5, 7].

У травні 1923 р. розпочало свою діяльність Українське історично-філологічне товариство (далі - УІФТ) у Празі, яке було засноване за ініціативи батька молодого вченого, Дмитра Антоновича, та групи професорів філософічного факультету УВУ (В. Біднова, Дм. Дорошенка, О. Колесси, В. Щербаківського та П. Андрієвського). Як відомо, Товариство досить швидко згуртувало навколо себе провідні наукові сили української еміграції не лише у Чехословаччині, але й з-поза ії меж. Чисельність членів Товариства невпинно зростала і поповнювалася представниками молодої наукової генерації, серед них був і Михайло Антонович. Дійсним членом УІФТ М. Антоновича було обрано 27 червня 1933 p. [25, с. 90]. Хоч історик на той час перебував у Бреслау (тогочасна Німеччина), однак для виголошення доповідей приїздив до Праги на засідання Товариства, а відтак - не переривав «живий зв'язок» [18, с. 197-198] з науковим осередком. Доповіді автора, виголошені за всю історію діяльності УІФТ (1923-1938рр.), були здебільшого присвячені історії України та українській історіографії. Окремі праці науковця були видані УІФТ $[1 ; 3 ; 4 ; 5 ; 6]$. Детальний огляд цих праць вченого подав А. Шаповал [25]. С. Наріжний у монографії також відзначав, що завдяки пожертві М. Антоновича та інших стало можливим видання III та IV томів «Праць» Товариства, що побачили світ у 1941 р. [18, c. 208; 24, c. 208-209]. У 1932 p. М. Антонович також брав участь у роботі II Українського Наукового з'їзду в Празі з доповіддю «Князь Рєпнін як правитель Саксонії» [11, с. 138].

31936 по 1941 pp. Михайло Антонович був науковим співробітником Українського наукового інституту в Берліні (далі - УНІ), заснованого у 1926 р. за ініціативи гетьмана П. Скоропадського. Водночас, працював у Бреславському університеті (суч. Вроцлав, Польща) у професора Ганса Коха ${ }^{2}$ та у Відні, будучи доцентом університету. Висвітлюючи масштабну діяльність УНІ в Берліні, С. Наріжний писав: «В пізніших роках багато працював у різних німецьких архівах асистент Інституту Д-р Михайло Антонович - самий надійний із повоєнного покоління українських істориків - що в цей час займає становище наукового співробітника в Східньому Інституті в Бреславі (3 1937 р. по 1941 р. М. Антонович був науковим співробітником історично-політичного відділу Інституту Східної Європи [25, с. 93]). Опубліковані праці цього дослідника зв'язані переважно з українсько-німецькою та східноєвропейською тематикою взагалі» $[18$, с. 216]. Як писав у своїй автобіографії М. Антонович, у Берліні він навчався завдяки стипендії УНІ [11, с. 138], науковим співробітником якого він залишався до 1937 р. [25, с. 89].

О. Оглоблин в «Огляді української історіографії» писав, що УНІ в Берліні, який перебував під науковим впливом Д. Дорошенка та В. Липинського, виховав цілу генерацію вчених, куди входили Б. Крупницький, Д. Олянчин, І. Лоський, В. Кучабський, М. Антонович, П. Вергун [29, p. 401]. Ця наукова генерація працювала в галузі української історичної науки в 30-их pp. Серед її представників був і Мих. Антонович (якого О. Оглоблин назвав «багатообіцяючим»).

У Берліні молодий науковець захистив докторську дисертацію на тему «Князь Рєпнін - генералгубернатор Саксонії» (Берлін, 1936). Рецензію на працю написав відомий історик права Микола Чубатий. Вона була опублікована в науково-літературному журналі «Дзвони» (Львів, 1937). М. Чубатий писав, що розвідка М. Антоновича $\epsilon$ «науково вартісною», однак з подивом запитував, чому дослідник вибрав «таку далеку нам тему», адже можна було б підшукати наукову проблему більш пов’язану 3 українським минулим [23, с. 62]. Про своє зацікавлення особою Миколи Рєпніна Михайло Антонович писав у листі до письменника Василя Юхимовича (Шимка?³) від 23 лютого 1944 р. з Бреслау. Оповідаючи про трагічну долю князя, відзначав його зусилля у відновленні повоєнного устрою Сак-

\footnotetext{
${ }^{2}$ Ганс Кох - директор Інституту Східної Свропи в Бреслау з жовтня 1937 по 1940 pp. М. Антонович присвятив Г. Коху працю «Студії з часів Наливайка».

${ }^{3}$ Василь Шимко - письменник, автор новел «Степові звитяжці», «Син», «Чорної ночі», «3 півночі вітер», «Коли падає листя жовтаве» та ін., редактор часопису «Чужиною» (Німеччина), автор розвідок «Україна й Росія», «Конотопський бій», «Останні дні гайдамаччини», «Іван Богун», «Симон Петлюра» та ін., секретар Літературно-мистецького клубу в Торонто. В листі до Любомира Винара від 12 грудня 1985 р. Марко Антонович писав: «...додаю лист мого брата до Василя Шимка» [11, арк. 1].
} 
сонії та зв'язки з Україною [15]. Дослідник працював в архівах Дрездена, Берліна, Кенігсберга, Гданська (тогочасний Данциг), в архівах Польщі [12, с. 116]. Як відзначав О. Оглоблин, саме там історик зібрав доволі багато нового матеріалу до історії України XVI-XVIII ст. Окрім того, він був одним із перших, хто зацікавився дослідженням українсько-німецьких взаємин у XVIII ст. [29, р. 425].

Вважаємо, що наукові зацікавлення історика остаточно сформувалися у 20-30-их рр. та були зосереджені на вивченні історії України XVI-XIX століть, зокрема козацького періоду. Становлення молодого науковця відбулося завдяки авторитету та підтримці його батька, Дмитра Антоновича, ректора УВУ, члена УНІ в Берліні, голови УІФТ, директора Музею визвольної боротьби України у Празі [24, с. 203, 220], відомого історика мистецтва та театру, активного політичного та громадського діяча. Між батьком і сином велося активне листування, підтримувалися не лише теплі, родинні стосунки, науковці активно обмінювалися думками, ідеями, обговорювали наукові та організаційні справи, бібліографічні новинки тощо [24, с. 207-208, 220, 223].

Більшість досліджень М. Антоновича присвячених українській історії, написані у формі науковопопулярних нарисів. Напередодні та в час Другої світової війни М. Антонович опублікував кілька розвідок з історії козаччини, зокрема «Козацьке військо у Смоленській війні» (Варшава, 1937), «Козацький проект Василя Капніста» («Сьогочасне і минуле», 1939, № 2), «Матеріали до вербування українців у пруську армію XVIII ст.» в «Працях» Українського історично-філологічного товариства в Празі, т. 2: на пошану голови Товариства проф. Дм. Антоновича (Прага, 1939), «Студії з часів Наливайка» (Прага: УІФТ, 1941), «Переяславська кампанія 1630 р.», видана у «Працях» УІФТ в Празі (т. 5, Прага, 1944) та ін. Деякі дослідження молодого науковця, у тому числі монографія про гетьмана Петра Конашевича-Сагайдачного, залишилися неопублікованими. У 1941-1942 рр. була опублікована 4-томна «Історія України».

Крім українськомовних, М. Антонович друкував роботи й німецькою мовою у німецьких виданнях, відтак презентуючи українську науку в європейському та світовому масштабі. Зокрема «Geschichte der Ukrainischen Staatlichkeit» ${ }^{4}$ в кн. «Handbuch der Ukraine» (Leipzig, 1941), «Kultur der Ostslaven» ${ }^{5}$ (Breslau, 1941), «Ukraine in Russischen Reiche» ${ }^{6}$ (Wien, 1942). Як відзначав C. Наріжний, деякі німецькі пресові органи завдяки співробітництву в них авторів-емігрантів, систематично інформували про українські справи німецьке суспільство. Деякі з них випускали спеціальні числа, присвячені Україні (напр. німецький тижневик «Німецька професійна освіта» у 1938 р. випустив таке українознавче число зі статтями українських авторів-емігрантів: М. Антоновича, Б. Крупницького, I. Мірчука, Р. Димінського, 3. Кузелі та ін.).

Інтелектуальне коло Михайла Дмитровича Антоновича включало Дмитра Антоновича, Романа Димінського, Володимира Дорошенка, Мирона Кордубу, Ганса Коха, Бориса Крупницького, Зенона Кузелю, Івана Мірчука, Володимира Міяковського, Олега Кандибу (Ольжича), Олександра Оглоблина, Василя Сімовича, Степана Сірополка, Дмитра Чижевського, Василя Шимка та ін.

Про приватне життя М. Антоновича (домашне ім'я Мурик) знаємо мало. Відомо, що його дружина була німкенею на ім'я Гелена (Лєночка) Швебель [20, с. 86]. У 1944 р. у пари народилася донька Раїна (Антонович-Вольф), яка вже у дорослому віці листувалася із своїм дядьком Марком Антоновичем [14]. В некролозі на пам'ять Марка Антоновича вона писала: «Свого батька, Михайла Антоновича, я не пам'ятаю, а контакти з його родиною були обмежені до радше формальних листів. Виною цього була, з одного боку, велика віддаль між нами, а з другого - мабуть, бажання моєї мами (німкені) затримати мене у своєму світі і під своїм впливом» [1, арк. 1].

31941 по 1942 pp. М. Антонович перебував в Україні як перекладач при штабі групи армії «Південь», але ймовірніше його перебування в Україні зв'язане з діяльністю похідних груп ОУН та О. Ольжичем, з яким М. Антонович підтримував тісні дружні відносини [11, с. 141]. М. Барбон у своїх споминах стверджував, що Михайло Дмитрович мав німецьке громадянство (через дружину німкеню), а відповідно був військовозобов'язаний [9; 17]. Таїса Ківшар, спираючись на матеріали надані Красноярським Товариством «Меморіал», спростовує таке твердження. У цей час вчений активно цікавився українським культурно-громадським та науковим життям. Відвідав Маріуполь, Харків [25, с. 93-94], Київ, побував на Кубані [9; 17]. Під час перебування у Маріуполі до Михайла приїздив його батько, Дмитро Антонович, згодом і брат, Марко [24, с. 224-225]. Повернувся Михай-

\footnotetext{
${ }^{4}$ «сторія української державності».

5 «Культура східних слов'ян».

${ }^{6}$ «Україна в складі Російської імперії».
} 
ло Дмитрович з України восени 1942 р. і після цього проживав із сім'єю в Бреслау, де продовжував свою наукову працю. У листі від 6 січня 1943 р. до М. Кордуби повідомляв, що у Відні склав габілітаційний іспит (грудень 1942 р.) та працював над матеріалами архіву імператорського двору і дому, відділу австрійського Державного архіву у Відні [10, с. 275] та активно цікавився українським науковим життям в Україні та закордоном [10, с. 276]. 3 капітуляцією Німеччини Михайло Антонович 3 родиною залишився в Берліні, де будь-що намагався врятувати цінну бібліотеку УНІ-Б. А. Шаповал відзначив, що у листі до матері Михайло Антонович писав, що прикладом для нього був батько, який би у подібних обставинах не покинув би колекції МВБУ [цит. за: 24, с. 229].

У 1945 р., 4 липня, М. Антонович був арештований або у Парижі [9, с. 135], або (ймовірніше) у Берліні $[28$, с. $107 ; 11$, с. 144] та депортований до СРСР. За свідченнями колишніх ув'язнених, до середини 1950-х років перебував у радянських концтаборах поблизу Норильська та Колими. Згадки про зустріч і знайомство з істориком містяться в споминах Миколи Барбона, котрий перебував в норильському 2-му політичному таборі «Кайєркан» у 1951-1952рр. Він згадував, як вперше побачив високого, міцної статури чоловіка з великою головою та високим чолом Сократа, котрий захоплювався українською мовою, ії витоками, розповідав про національний пам'ятник українського народу - київський Золотоверхий собор, зруйнований більшовиками [9; 17]. Перебуваючи у тому ж таборі, В. Тимощук писав, що житомирянин, свідомий українець, Михайло Пилипчук повідомив йому, що серед новоприбулих є «визначна для України особа - історик Михайло Дмитрович Антонович». Згодом відбулося і безпосередне знайомство В. Тимощука з М. Антоновичем, якого він описав так: «На вигляд це була людина трохи вища середнього зросту та міцної будови. Привертали увагу велика голова $з$ глибокими залисинами, розумні сірі очі. Мав русяве волосся із сивиною та короткі вуса. Коли Антонович назвався і стиснув мою руку, в мене промайнула думка, що це видатна людина. Голос його лунав виразно і рівномірно» [22, с. 143]. В. Тимощук згадував неабияку ерудованість історика, унікальну пам'ять та знання. Т. Ківшар у своїй розвідці, використовуючи матеріали Красноярського товариства «Меморіал», зуміла відтворити та уточнити важливі біографічні дані останніх років життя вченого [11, с. $143-151]$.

М. Антонович й у важких умовах таборового життя переймався тодішнім становищем України, iї політичними перспективами. Та головно, ніколи не полишав писати історію України, незважаючи ні на що [22, с. 144]. Читав лекції, присвячені історії слов'ян, України, Росії, стародавнього світу [9; 17]. Окрім того, протестував проти нелюдських умов утримання та праці ув'язнених табору, взяв участь у відомому Норильському повстанні влітку 1953 р. [11, с. 148-150].

Збереглася поштова картка, можна сказати «останній лист» Михайла Антоновича до німецького Червоного Хреста від 12 квітня 1955 р. у справі розшуку місця перебування його дружини та сестри, опублікована в «Українському історику» [20, с. 87].

М. Антонович помер у Магаданській в'язниці, на Колимі, дати смерті, згадувані в літературі, різняться. Т. Ківшар вважає ймовірною датою 23-24 квітня 1955 р. [11, с. 151]. Втім, ми встановили, що у відповідь на запит Гелени Антонович до Служби розшуку (Гамбург) № 750 від 8 грудня 1956 р. надійшла офіційна відповідь Виконавчого комітету спілки товариств Червоного Хреста та Червоного Півмісяця СРСР від 3 квітня 1957 р. про те, що ії чоловік, Михайло Антонович, нар. 1910 р., перебуваючи в ув'язненні за адресою: п/с (поштова скринька. - Н. К.) 5110/35 помер 24 листопада 1955 р. $[20$, c. 88,19 , арк. 1]. Відомий філолог Я. Рудницький (чоловік сестри Михайла Марини) у своїх споминах стверджував, що ще на початок 60-тих рр. про М. Антоновича надходили вістки, а відтак дата та місце смерті історика невідомі [20, с. 86].

Детальніше розглянемо історичні та політичні погляди історика, його бачення місця та ролі України в світовому історичному процесі. Як було згадано вище, протягом 1941-1942 рр. побачила світ 4-томна «Історія України», що вийшла друком у Празі в серії «Наукова бібліотека» видавництва Юрія Тищенка. Обкладинка була виконана відомим українським художником та графіком, професором Української студії пластичного мистецтва в Празі Робертом Лісовським. Перший том праці присвячений княжій добі та хронологічно охоплює період від найдавнішого часу до XIV ст.; другий охоплював «Литовсько-руську добу» (XIV-XVI ст.); третій - «Козаччину та Гетьманщину» (XVIXVIII ст.) та четвертий - «Нову добу» (XIX - поч. XX ст.).

Праця $\epsilon$ певним синтезом поглядів та оцінки істориком визначних подій, явищ та процесів історії України. «Історія України» одержала низку критичних зауважень та рекомендацій. Зокрема, як писав М. Антонович до М. Кордуби в листі від 8 вересня 1943 р., такі зауваження та рекомендації автор 
отримав не лише від М. Кордуби, а й від Д. Чижевського та О. Оглоблина. Рекомендації першого були надіслані окремим листом, однак через певні обставини були втрачені та М. Антонович просив М. Кордубу надіслати їх ще раз, адже працював на другим виданням 4-томника [10, с. 276].

У вступі до своєї праці М. Антонович зазначав, що саме колонізаційний рух на схід, колонізаційний процес освоєння українських земель став визначальним фактором у розвитку української державності, а національний чинник мав лише другорядне значення [1, с. 5; 29, р. 425]. Оцінка процесу державотворення істориком $\epsilon$ відмінною від популярних ідей державницького напряму початку XX ст. (напр. В. Липинського, С. Томашівського, Д. Дорошенка та ін.), що відзначав і Борис Крупницький у своїй праці «Історіознавчі проблеми історії України». Зокрема, автор твердив, що Михайло Антонович у своїй праці «Історія України» на перший план висуває колонізаційний процес, якому надає найбільшої ваги в оцінці історичного розвитку України, але «це тільки жест, бо ця думка не доводиться консеквентно (поступово. - H.К.) на сторінках його ж історії. Зате консеквентним був д-р М. Антонович у своїм стремлінні довести, що українська державність $\epsilon$ перейдений етап української історії» [12, с. 6-7]. Не погоджуємося з таким твердженням Б. Крупницького, адже державницька ідея наскрізно присутня в науковому доробку М. Антоновича, однак ця ідея $\epsilon$ певним синтезом різних історіографічних напрямів і має цілком оригінальне авторське обгрунтування.

Історики-державники, на думку М. Антоновича, «вишукували в історії властиво лише те, що можна було підтягнути під ідеали модерної національної держави» $[1$, с. 7-8]. Причиною такого «підтягнення» були європейські тенденції розвитку історичної науки після Першої світової війни. Опонуючи державникам, історик твердить, що держава має значення лише як одна з функцій національного життя, як орган забезпечення розвитку народу - лише в цьому випадку її існування виправдане. Вона $\epsilon$ засобом, а не самоціллю [1, с. 7-8]. Відповідно в часи, коли національного почуття в теперішньому розумінні не існувало, інші політичні форми гарантували розвиток народу, який зовсім не прагнув окремішності та самостійності, розглядаючи себе як частину інших держав, які могли розв'язати його проблеми та завдання.

М. Антонович проводить цікаві паралелі історичного розвитку. Автор пише, що у XVIII ст. єдиною гарантією релігійної свободи була приналежність до однієї віри народу і його володаря. Різні привілеї та обіцянки рятували від утисків, не більше ніж демократичні конституції модерну національну меншість. Згодом прийшли часи релігійної толерантності. I рано чи пізно знайдеться така можливість і для національності, хоч напевне не в рамках бюрократичної держави $[1$, с. 8-9].

Найважливішим, на думку М. Антоновича, є забезпечення вільного розвитку народу, а яка саме організаційна форма цей розвиток гарантує - це річ другорядна. Саме тут можна простежити певні прогностичні оцінки вченого щодо глобальних та інтеграційних тенденцій розвитку європейської політики на сучасному етапі розвитку міжнародних відносин.

Давня історія України в праці історика носить описовий та загальний характер, подається з точки зору заселення території України різними народами. Детальніше дослідник розглядає князівську добу. Провідну роль у формуванні Київської держави, на думку автора, зіграв Київ - місце зосередження капіталу і центр, з якого перші київські князі (Олег, Ігор, Ольга, Святослав) розпочали боротьбу за контроль над вигідними торгівельними шляхами $[1$, с. 23-25]. В часи зміцнення князівської влади найважливішою подією, вважав М. Антонович, стало прийняття князем Володимиром християнства як «акту державної необхідності» [1, с. 26], який мав закласти подальші підвалини міцної держави. Малося на увазі, що нова церковна організація повинна була стати на службу державі і запорукою їі міцності. Духовенство мало розробити концепцію єдиновладдя «цісаря». Однак, воно було грецьким, чужим, і коротке перебування на митрополичій кафедрі Іларіона нічого не змінило: «Провина за політичну недальновидність падає на інтелектуально провідну верству - духовенство» [1, c. 33], а звідси є причиною політичної роздробленості Київської держави.

М. Антонович з критикою та без пієтизму висвітлював постать Данила Галицького та особливості формування Галицько-Волинської держави. Татарський чинник та дії ворожого війська на руських землях вважав не більше ніж військовою «гроельпропагандою» (з нім. - грізною, загрозливою) проти орди $[1$, с. 52]. Писав, що зовнішньополітичні амбіції князя лише штовхали державу до нових війн і катастрофа його планів призвела до смерті князя та «припечатала долю Галицько-Волинської держави, що залишилася скалком української території рано чи пізно засудженої на загубу серед сильніших сусідів» [1, с. 47-56]. В описі устрою та побуту князівської доби автор підкреслював колективне прийняття рішень князем та дружиною, з якої згодом сформувалося боярство; значення 
«Руської правди»; роль віча в житті міст; категорії селянства та ін. Говорячи про особливості релігійного життя, автор стверджував, що чернецтво хоч і виконувало роль інтелектуального провідника, однак було відірване від політичних проблем сучасності і відтак не спромоглося витворити ідеологію єдиного володаря, єдиної держави, а займалося лише щоденною боротьбою з демонічними силами для врятування власної душі [1, с. 73-74].

Литовсько-польська доба постає в творчості М. Антоновича добою несправедливо забутою та маловивченою, яка не підпадала під рамки сучасних (М. Антоновичу. - Н.К.) уявлень про державу в порівнянні з політичними утвореннями Київської та Галицько-Волинської держав [3]. Зауважимо, що том, присвячений литовсько-польській добі, $є$ структурно та змістовно повнішим. Автор стверджував, що провідна верства Великого Князівства Литовського зуміла при збереженні всіх етнічних особливостей кожного поодинокого народу виробити загальне «литовське» державне почуття і патріотизм [3, с. 5-6]. Таким чином, автор ще раз підтверджував свою думку, що головним чинником $\epsilon$ вільний розвиток народу, а організаційна форма $є$ річчю другорядною.

М. Антонович детально простежив генезу литовського народу, колонізацію литовських земель орденами хрестоносців, початки першої політичної організації, відносини з слов'янськими племенами, згодом Київською Руссю, боротьбу та союзницькі відносини з галицько-волинською землею, період могутності ВКЛ часу Ольгерда та Вітовта, діяльності яких приділено автором неабияку увагу, а також періоду політичної боротьби внутрішніх і зовнішніх сил за владу у ВКЛ та Польщі [3, с. 7-31].

Говорячи про причини унійних прагнень, дослідник твердить, що саме «бажання визволитися від влади своїх панів прибрало серед українського земянства форму стремління до тіснішої унії 3 Польщею, і нерозлучно зв'язаного з тим перебрання внутрішніх польських порядків» [3, с. 50-51, 71-72]. Окрім того, передумовою зближення держав, історик називав культурний занепад українських земель, внаслідок татарських нападів, спустошення Подніпров'я та перенесення культурного життя далі на захід, до Польщі.

Дослідник зазначав, що саме прорахунки польських королів у зовнішній політиці призвели до посилення Московської держави, вістря якої повернулося і проти території Литви-Русі, а згодом і Речі Посполитої та сприяло розширенню московських кордонів. Саме це стало одним із вирішальних чинників у зближенні Польщі та Литви-Русі [3, с. 54-60]. Говорить, що у XVI-XVII ст. оживляється в Україні зацікавлення релігійними проблемами, яке $\epsilon$ свідченням того, що християнство, прийняте в попередній добі лише вищими верствами суспільності, почало просочуватися і в низи [3, с. 70]. Характеризуючи побут та культуру України литовського періоду, автор окреслив основні характерні умови та ознаки соціально-економічного становища селян, міщан (зокрема відзначав роль братств у культурному розвитку українських земель), духовенства (яке було чуже, відірване і непридатне захистити українські інтереси), шляхти та магнатів, життя яких супроводжували постійні сварки та свавілля. М. Антонович писав: «Та що безумовно вражає у довгих реєстрах вибриків, злочинів і насильств таких свавільців, це нестримна дика життєва енергія, яка шукала собі виходу в напруженій діяльності, у безнастанних чварах та зачіпках» [3, с. 73-74]. 3 тих, які спрямовували цю енергійність на боротьбу з татарами, вийшли провідники нової суспільної верстви - козацтва, з ними пов'язані початки військової організації [3, с. 73-74].

Проводячи паралелі з європейською історією, М. Антонович приходить до висновку, що панська олігархія Литви-Русі занепала не в часах слабкості, кризи та безпорадності, а після проведених успішних реформ та військових перемог над ворогами. Що основна хиба панів-ради була загальноукраїнською - неспроможність витворити належну теоретично-політичну концепцію. I не варто забувати, що Люблінська унія була чинно сприйнята українським поспільством. А коли вона, на думку М. Антоновича, як показала історія, стала політичним промахом і потягла за собою безкінечну низку кривавих конфліктів, то провина за це лежить, насамперед, на українцях [3, с. 76-77].

Козаччина найбільше цікавила М. Антоновича і стала провідною темою його наукових дослідів як явище цілком оригінальне та виняткове в українській історії. У своїх поглядах на козаччину та Гетьманщину історик здебільшого опирався на сучасні йому наукові здобутки української історіографії. Він проаналізував особливості початків козацтва, зокрема походження, перші форми боротьби, діяльність перших козацьких ватажків, побудову січей, початок формування козацтва як політичної сили, вихід на міжнародну арену, військові кампанії тощо [4].

Колонізація на південь, що була ініційована не державою, яка була слабкою, а відомими родами Острозьких, Вишневецьких, Корецьких, Збаразьких сприяла нарощенню економічного потенціалу 
Речі Посполитої, адже лише кількатисячні князівські війська могли оборонити новозаселені землі від небезпеки [4, с. 96-97]. А відтак, притік населення у магнатські землеволодіння спричинив утворення величезних латифундій, де становище селян та козаків все більше утискалося. Незважаючи на це в своїй основі козацький рух довго лишався «внутрішнім міжкласовим антагонізмом» [4, с. 17]. Саме такий характер мали повстання К. Косинського, Г. Лободи, М. Шаули, С. Наливайка [6].

Останньому, а точніше його часам, присвячена окрема розвідка «Студії з часів Наливайка» (Прага, 1941), в якій використані та опубліковані у додатках матеріали державного архіву в Данцигу. Відгук на цю працю написав проф. Мирон Кордуба, за що М. Антонович дякував у своєму листі від 6 січня 1943 р. з Бреслау. У. Великопольській вдалося виявити в бібліотеці Львівського національного університету ім. І. Франка примірник цієї роботи, який М. Антонович надіслав М. Кордубі з дарчим надписом: «Проф. Др. М. Кордубі від автора» [10, с. 277]. У цьому нарисі автор звертав увагу на особливості отримання козаками цісарської хоругви, специфіку переговорного процесу між козаками та представниками австрійського цісаря Рудольфа II, що тривали з весни до осені 1594 р. Ці козацькі намагання стати на цісарську службу сприймалися польським суспільством як зрада. Водночас, для козаків це був вияв політичної самостійності. Свропейські події кінця XVI ст., розгортання австрійсько-турецького протистояння, сприяли зростанню військової підприємливості козаків, які намагаються вибороти собі права та привілеї, активно впливаючи на внутрішне, так і зовнішнє становище Речі Посполитої (військові походи під проводом Г. Лободи, Б. Микошинського) [6, с. 15-20]. На час налагодження відносин з козаками і залучення їх до антитурецької коаліції припадає зростання авторитету амбітного «кондотьєра» Северина Наливайка, що вилилося в чергові військові походи «наливайківців» та січовиків до Молдавії [6, с. 23]. Окрім того, автор стверджує, що після кампаній весни 1595 р. та розриву з січовиками С. Наливайко намагався стати самостійним учасником міжнародних перемовин $з$ цісарем і не лише з ним [6, с. 44]. Однак діяльність його обмежувалася лише грабунком та квартируванням козацьких відділів. Історик писав: «Серед них (козаків. - H.К.) не було ні одної видатнішої постаті з ширшим політичним світоглядом, яка б зуміла одушевити вояцькі маси ідеєю вищою ніж погранична жандармерія, яку проектував Наливайко» [6, с. 47].

У розвідці автором також проаналізована активна діяльність відомого київського єпископа Йосифа Верещинського, автора проектів перетворення козацького війська на лицарський орден для оборони України від татар. Цей католицький симпатик козацтва пропонував створити самостійну козацьку державу на схід від Дніпра, на чолі з князем, яка б перебувала у васальній залежності від Польщі. Хоч проект був написаний «на коліні», але вказував не так на реальні можливості, як на те, що сучасники вважали за можливе і здійснене [6, с. 54-55, 56-61].

М. Антонович проаналізував умови та обставини, в яких довелося козацтву взяти на себе функції захисника не лише станових, а й національних інтересів. Зокрема, це полонізація, окатоличення, занепад православної церкви, прийняття Берестейської унії, діяльність Петра Конашевича-Сагайдачного, козацькі повстання 20-30 pp. XVII ст. тощо [4, с. 23-37]. Окрім того, в листі до М. Кордуби від 8 вересня 1943 р. повідомляв, що: «Монографію про Сагайдачного я вже закінчив і здав до друку, але в коректі доведеться робити ще чимало поправок, власне доповнень, бо цього літа вдалось мені попрацювати над актами з бібліотеки Рачинських, де я знайшов чимало нового матеріялу. 3 легендою про Сагайдачного як про лояльного підданого Речі Посполитої, думаю, вдалось мені скінчити. Взагалі, мало не на цілім фронті довелося звернутися проти висновків (не стверджень) Грушевського» [10, с. 277]. Праця так і не була опублікована, доля iї на сьогодні, на жаль, невідома.

Чільне місце в дослідженнях історика належить добі Хмельниччини. Однією з важливих причин викристалізування позиції українського табору був вплив міфологізації та інформаційного чинника, зокрема «дражнення заможного, певного своєї сили, населення» $[4$, с. 39] творчою силою козацької верстви. М. Антонович писав: «Вона (козацька верства. - Н.К.) хотіла влади і зуміла ії добитися, а розповсюджуваними легендами про панську тиранію творила моральне оправдання для цеї своєї влади і для всіх своїх вчинків» [4, с. 39]. Саме завдяки пропаганді Б. Хмельницький зумів «потягти за собою цілий нарід» [4, с. 40].

Історик відзначає, що приїзд та зустріч Б. Хмельницького у Києві, розпочали процес зародження політичної ідеї теоретичної спільності земель і монархічності гетьмана як Богом вибраного володаря, хоч, відзначав, що такі ідеї важко були зрозумілі не лише для суспільства, але й для його найближчих сподвижників. Унікальність такого розуміння лежала в площині відношення до рівня аристократичності. У Європі носієм культури, в тому числі політичної, була гербова шляхта, для 
української дійсності - козацтво, представники, здебільшого, нижчої верстви, які вже у наступному столітті намагалися стати шляхтичами. Підписання Переяславського договору дослідник вважав слабиною української політичної думки: «не дивлячись на всю ненависть до Польщі, маса населення не спромоглася засвоїти собі поняття, що вже послух Богом даному гетьманові сам по собі звільняє від підданства королеві. Провідні круги цю тезу хіба назначили, але не вщепили їі суспільству. Але що цар може звільнити від послуху королеві було масам відразу ясно» [4, с. 47].

Доба Руїни та прихід до влади І. Мазепи показали капітуляцію гетьманської влади перед претензіями старшини, що призвело до утвердження на території Гетьманщини аристократичної олігархії. Аристократична республіка була пережитою формою устрою, а XVIII століття стерло їі взагалі 3 лиця землі, і Україна розділила долю Польщі та Венеції. Майбутнє належало бюрократичним державам $з$ міцною центральною владою [4, с. 67, 76-95].

Ліквідовуючи залишки автономії та нищачи козацьку верству, російські монархи стали протекторами українських міст та міського населення, а також духовенства, які перебували у певній відірваності від національних інтересів. Блиск української православної культури XVII-XVIII ст. не був на користь Гетьманщині. Духовенство, покликане до витворення державної ідеології, назагал не зуміло знайти спільну мову з козаками. Лише П. Конашевичу-Сагайдачному та Б. Хмельницькому вдалося досягти на короткий час порозуміння з церквою [4, с. 101-103, 108-109]. Гетьманщина, як і колись Литва-Русь, впала під ударами аристократичної анархії та олігархії.

Останній, четвертий том «Історії України» М. Антоновича присвячений ХІХ століттю, «новій або російській добі» $[5$, с. 6]. Оцінюючи процеси початку нової епохи, автор критично підходить до розуміння доби, яка на його думку, невиправдано названа в історіографії «національним відродженням». Поява праці І. Котляревського, яку вважали наріжним каменем цього явища, незважаючи на мистецьку вартість «Енеїди», навіть не викликала якогось потужного літературного руху і тим більше «не могла вплинути на величезне сплетиво політичних, соціальних, духовних та економічних елементів, що 3 них складається життя нації» [5, с. 5-6]. І відповідно з року появи твору не варто розпочинати відлік національного відродження - під яким М. Антонович розумів процес стремління народу до самобутності у всіх ділянках суспільного життя. А «Енеїда», на його думку, не відповідала таким новим стремлінням.

Релігія стала тим фактором, що зміцнив тривалий зв'язок між Україною та Росією, в порівнянні 3 Польщею. Адже Росія стала справжнім оборонцем тих народних інтересів, котрі в XVII-XVIII ст. мали величезну вагу для українського суспільства, насамперед релігійних. Окрім того, колонізаційна політика російської держави, що відкрила доступ до Чорного моря і сприяла економічному розвитку українських земель, стала ще одним чинником поглиблення відносин. Третім аспектом був патріотизм, який зводився лише до доведення перед росіянами вірності імперії та царю, а поява перших історичних праць якраз і відображала означену позицію українців, які і допомагали розбудовувати російську державу. Водночас, причинами, які гальмували злиття двох територій, були, як вважав М. Антонович, столітні особливі шляхи розвитку України, відмінність економічних та духовних інтересів, врешті повна протилежність характерів обох народів [5, с. 8-12]. Місія Василя Капніста до Берліну в 1791 р. чи діяльність В. Лукашевича під час французько-російської війни були нічим іншим як поодинокими виступами «шляхетської фронди». А козацька верства, що переймалася своїми власними економічними та становими інтересами, була вповні, незважаючи на спроби відновлення козацтва як військової одиниці (заходи Я. Лобанова-Ростовського та М. Рєпніна), розчинена в межах російської держави.

Перші ознаки літературного відродження, на думку автора, з'явилися не в Гетьманщині, а в Слобідській Україні і були пов'язані з діяльністю Г. Квітки-Основ'яненка та літературного руху, який ставив собі за мету вживання народної мови. Ця літературна традиція не переривалася і призвела до витворення нової української писемності [5, с. 24-25].

М. Антонович писав, що у середині ХІХ ст. народилася нова верства - інтелігенція, яка виступила в обороні того, що, на їі думку, найсвятіше для людини - національно-культурне обличчя. Спочатку діяльність цього прошарку перебувала в аполітичній площині, однак згодом з'явилася ідея політичного сепаратизму, як єдиного засобу забезпечити існування своєму народу. А відтак, «з моментом появи нового принципу суверенності, як результату занепаду шляхти і наростання нових правлячих кляс, допустимо починати в історії України добу, котру можна називати «національним відроджен- 
ням». Правильнішим означенням було би, очевидно, «доба модерного націоналізму»... Завжди існувавше патріотичне почуття прийняло тільки нові форми» [5, с. 38-39].

I відлік такої доби варто розпочинати діяльністю Кирило-Мефодіївського братства. Говорячи про особливості поглядів кириломефодіївців М. Антонович відзначив одну особливість. Неполітична любов до Батьківщини для І. Котляревського та Г. Квітки-Основ'яненка була могутнім стимулом їхньої літературної діяльності. I ця неполітична любов в братстві виступає в незвично активній формі. Звичайно, вона мала мало чого спільного з нинішнім (початку ХХ ст. - H.K.) національним почуттям, але змогла витиснути державний (проросійський. - H.К.) патріотизм на другий план. Особливо це спостерігається у Т. Шевченка, який став провісником модерного націоналізму з гаслом національних інтересів понад усе. Він перший в українській політичній думці зідентифікував царя з гнобителями росіянами і відкинув його як «чужонароднього» господаря. I взагалі, вперше у Т. Шевченка 3'являється думка, що Україна пригноблена. Для Т. Шевченка змінився цілий сенс історичного процесу: не злиття Мало- і Великоросії, не триєдинство Русей, а самостійне буття України як найвища ціль [5, с. 41-42]. Братство здійснило «світоглядний переворот». Ідеї та твори кириломефодіївців були строкаті і свідчили про їхні ідейні хитання, але згодом були оцінені і по-новому трактовані вже молодшою генерацією.

Соціально-економічні труднощі підросійської України були зумовлені і внутрішніми і зовнішніми обставинами, які спричинили великий колонізаційних рух українського населення вже за межі етнографічних українських земель (Сибір, Крим, Кавказ, Приазов'я). Козацьке населення Кубані, подібно українській шляхті, своїм світоглядом і існуванням міцно поєднались 3 царською владою, залишалися на ідеї давнього патріотизму державного типу, що приглушував прояви модерного національного чуття [5, с. 52]. А це тягло за собою добровільне прийняття ними російської мови та культури. Наслідки цього процесу можемо спостерігати і в сучасну добу, особливо в умовах російської агресії.

Повертаючись до значення колонізаційного руху, варто відзначити, що історик вважав, що такий процес мав і позитивні, і негативні наслідки для України. 3 однієї сторони були освоєні величезні простори, на яких інтенсивно розпочинає розвиватися промисловість, активізуватися торговоекспортні операції, зростати економічна потуга України, яка витягла їі «з ролі незначної, рідконаселеної території на межі з азіатським варварством до значіння економічного тіла, якого ненормальний розвиток мусить відчувати господарство цілої Европи» [5, с. 54]. А з іншого - колонізаційний рух на південний схід переніс центральну вісь національного життя з лінії Київ-Львів на Донбас 3 його русифікованим, а здебільшого чужим та прийшлим населенням, що стало найважливішою причиною слабкості України в сучасності.

Розглядаючи еволюцію «модерного націоналізму» Михайло Дмитрович писав, що неполітичному громадівському руху 60-их pp. ХІХ ст. завдячуємо обгрунтуванню ідеї етнічної окремішності українського народу, просвітницькій діяльності та боротьбі з русифікацією. Процес русифікації серед нижчих верств суспільства 3 певним запізненням, але розпочався і мав добровільний характер. «Немає нічого природнішого для маси як наподоблювати своїх панів», - з сарказмом писав автор. Маса повторювала той самий процес добровільної русифікації, що кілька генерацій раніше зробила козацька старшина [5, с. 62]. Все що російське - для простого люду панське, а значить вище. Одним із знарядь русифікації служила і православна церква, лише сільські українські священики зберігали свою належність до «стихійного українства», але лише за інерцією, а не з позиції активної свідомості.

Відтак, культурне українство опинилося у сліпій вуличці [5, с. 64]. Вчений вважав, що політизація українського руху в кін. XIX ст., з якою зв'язана активна діяльність М. Драгоманова, мала ті ж вади, що і політична думка України литовсько-польського періоду. Правда, тепер у формі співпраці з російським революційним рухом. На ідеалізоване переконання М. Драгоманова, Україна була пригноблена царизмом, і відповідно якщо він буде зруйнований, то нова вільна Росія залишить повну свободу Україні. «Консеквентно» продумала до кінця принцип суверенності народу, на якому базувалися усі політичні теорії XIX ст., тільки заснована у 1900 р. Революційна Українська Партія. Однак, ідея незалежності України не прижилася в тогочасному українському суспільстві, якого задовольняли ідеї автономії, максимум федерації. «Як і раніше, знову не вистачило українцям відваги думки і умового напруження, щоб засвоїти собі відповідний вимогам часу ідеал - національної держави» [5, с. 66-67].

Описуючи особливості становища західноукраїнських земель - Українського Закарпаття, Галичини та Буковини у «нову добу», М. Антонович виокремлює кілька специфічних рис. Зокрема, завдячуючи політиці Габсбургів, галицьке й буковинське селянство та греко-католицьке духовенство на 
початку XIX століття виробило позицію лояльності (хоч і в дечому відмінну одну від одної) до правлячого дому, яка збереглася аж до розпаду імперії. Карпатська Україна займала своїм культурним рівнем безперечно перше місце і саме з нею пов'язана хвиля культурного підйому [5, с. 72].

Початок національного відродження на західноукраїнських землях, який пов'язували з виходом літературного альманаху «Русалка Дністрова» та діяльністю членів «Руської Трійці», історик вважав невірним. Зокрема, відстоював думку, що відлік такого процесу варто розпочинати з революційних подій 1848 р. [5, с. 74-75]. У революційних та постреволюційних подіях свідоме українство відкинуло ідеологію лояльності до уряду, ідеалізовані уявлення про спільний українсько-польський рух, розчарувалося в ідеї москвофільства і спромоглося до витворення руху на основі народної мови та культури - «народництва», яке нав'язало активні контакти з Наддніпрянською Україною, хоча згодом теж стало на консервативні позиції [5, с. 77-79]. Навіть заснування нетривкої РУРП дослідник вважав наслідком духовної кризи розламу «Старої громади» М. Драгоманова, яку відчули і на Галичині.

М. Антонович писав, що сильний розвиток усіх ділянок національного життя в Галичині перед Першою світовою війною спричинив більшу готовність Західної України до майбутніх подій у порівнянні з Наддніпрянською Україною. Причина такого становища ховалася у досвіді парламентської боротьби австрійських українців, які зрозуміли, що українська проблема $є$ проблемою політичною. Водночас, мала ті ж хиби, що і в підросійській Україні - це був рух інтелігенції без буржуазії $[5$, c. 80$]$.

Закінчення Першої світової війни та розпад імперій поставив неготовий український народ перед необхідністю державного будівництва. В революційних змаганнях він зміг пройти шлях трансформації від етнічної маси до модерної нації, хоч і запізно. Здобутками революції історик вважав, те, що нарешті за кількасотлітню історію українство зрозуміло, що українське питання є політичним, а акт 22 січня знищив моральну спільноту між українцями та росіянами. Останні лише методом терору витворили й утримують нову «універсалістичну ідею» [5, с. 81-82] і в XXI столітті.

Окремо хочемо зупинитися на ролі особистості в дослідженнях М. Антоновича. Вчений не надавав особливого значення ролі та впливу індивіда на хід історичних подій. Здебільшого князі, бояри, козацькі ватажки, гетьмани, народні герої досить критично, з відкиданням історичного міфу оцінені істориком і виступають як певний додаток до процесів, які призводили до трагічних подій в історії України. Але, звичайно є і виключення. Зокрема, це постать Б. Хмельницького, індивідуальність якого зуміла залишитися для свого народу найвищою справедливістю. І такої індивідуальності після смерті гетьмана українцям забракло, писав М. Антонович [4, с. 51]. Високо оцінив вчений і постать провісника нової доби «модерного націоналізму» Т. Шевченка [5, с. 41].

Отож, можемо бачити, що погляд М. Антоновича на український історичний та політичний процес був цілком винятковим і акумулював різні історіографічні традиції - В. Антоновича, М. Грушевського, В. Липинського, С. Томашівського, Д. Дорошенка, О. Оглоблина та ін.

На думку історика, з часу Київської Русі саме українське духовенство мало виконати політичну програму оформлення та реалізації національної ідеї, а відтак саме на цю верству він покладав провину за невиконання такого зобов'язання перед народом. Окрім того, ідея аристократичної республіки, яка показала свою неефективність протягом кількох століть, мала вплив і на становище України у складі Росії. Вона породила ментальність вірності і незради. Антиросійські настрої залишалися в площині домашнього невдоволення, а проти зовнішнього ворога українська суспільність завжди готова була чинно підтримати царську політику. Сподіваємося, що завдяки Революції Гідності та агресії Росії проти України українці нарешті позбавляться цієї вірнопідданської ментальності і зможуть сформувати вільну національну спільноту та активне громадянське суспільство.

Політизація українського руху наприкінці XIX ст. показала неготовність української політичної думки до глибокої політичної кризи Європи початку XX ст. Розмірковуючи про майбутнє європейської політики та державність України, М. Антонович відзначав, що форма національної бюрократичної держави застаріла і показала свою неспроможність. Якою буде наступна державна фаза - невідомо. Але впевнено припускав, що «для нинішньої господарської зв'язаности цілого світу непереглядний ліс митних кордонів - неможливість, яка мститься. Будучина вимагає великих економічних територій» [5, с. 84-85]. Саме такий інтеграційний поступ можемо спостерігати сьогодні. Будемо сподіватися, враховуючи досвід та помилки історії, українська нація та держава займуть гідне та чільне місце в європейському політичному, економічному та цивілізаційному просторі. 


\section{Список використаних джерел та літератури:}

1. Антонович-Вольф Раіна. В пам'ять Марка Антоновича (оригінал німецькою мовою). Архів УІT (Архів Марка Антоновича). Ф. «Особові документи». 2 арк.

2. Антонович М. Історія України. Т. І: Княжа доба. Прага: Видавництво Юрія Тищенка, 1941. 80 с.

3. Антонович М. Історія України. Т. ІІ: Литовсько-Руська доба. Прага: Видавництво Юрія Тищенка, 1941. $80 \mathrm{c}$.

4. Антонович М. Історія України. Т. ІІІ: Козаччина та Гетьманщина. Прага: Видавництво Юрія Тищенка, 1941. $118 \mathrm{c}$.

5. Антонович М. Історія України. T. IV: Нова доба. Прага: Видавництво Юрія Тищенка, 1942. 89 с.

6. Антонович М. Студії з часів Наливайка. Прага: УФІТ в Празі, 1941. 81 с.

7. Антонович Михайло. Енщиклопедія Українознавства / за ред. В. Кубійовича. Словникова частина. Т. 1. Париж, Нью-Йорк: НТШ, «Молоде життя», 1955. С. 51.

8. Архів УІТ (Архів Марка Антоновича).

9. Барбон М. У Норильському концтаборі [про проф. М.Д. Антоновича]. Украӥнський історичний журнал. 1995. № 5 (404). C. 134-136.

10. Великопольська У. Епістолярій в особовому фонді Мирона Кордуби (з листів М. Антоновича до М. Кордуби). Пам'ятки: археографічний щорічник / Державний комітет архівів України; Український науководослідний інститут архівної справи та документознавства. Київ, 2008. Т. 8. С. 271-278. URL: http://hrushevsky. nbuv.gov.ua/cgi-bin/hrushevsky/person.exe?\&I21DBN=ELIB\&P21DBN=ELIB\&S21STN=1\&S21REF=10\&S21FM $\mathrm{T}=$ elib all $\& \mathrm{C} 21 \mathrm{COM}=\mathrm{S} \& \mathrm{~S} 21 \mathrm{CNR}=20 \& \mathrm{~S} 21 \mathrm{P} 01=0 \& \mathrm{~S} 21 \mathrm{P} 02=0 \& \mathrm{~S} 21 \mathrm{P} 03=\mathrm{ID}=\& \mathrm{~S} 21 \mathrm{STR}=0001882$ (дата звернення: $18 . \overline{1} 0.2019)$.

11. Ківшар Т. І. Автобіографія Михайла Антоновича як складова його наукової біографії. Українська біографістика. 2008. Вип. 4. С. 137-153. URL: http://nbuv. gov. ua/UJRN/ubi 2008410 (дата звернення: 20.10.2019).

12. Крупницький Б. Історіознавчі проблеми історії України (збірник статтей). Мюнхен: УВУ, 1959. 228 с.

13. Лист Марка Антоновича до Любомира Винара від 12 грудня 1985 р. з Монреалю. Архів УІТ (Архів Л. Винара). Ф. «Листування». Спр. «М. Антонович». 1 арк.

14. Лист Марка Антоновича до Раїни Антонович (Вольф) (Raina Wolff) від 1 січня 1985 р. $з$ Монреалю в Тюбінген. Архів УІТ (Архів Марка Антоновича). Ф. «Листування». 1 арк.

15. Лист Михайла Антоновича до Василя Юхимовича (Шимка) від 23 лютого 1944 р. з Бреслау. Архів УIT (Архів Марка Антоновича). «Листування». Спр. «Михайло Антонович». 3 арк.

16. Листи Михайла Антоновича до Олександра Оглоблина (1942-1944рр.). Архів УІТ (Архів Марка Антоновича). Ф. «Листування». Спр. «Михайло Антонович». 47 арк.

17. Микола Барбон: «Тайно Антоновича привезли на север Франции. Ночью в порту передали на борт советского торгового парахода в руки переодетых чекистов». URL: https://web.archive.org/web/20120310014709/ http://www.memorial.krsk.ru/memuar/Kasabova/08/05. htm (дата звернення: 21.10.2019).

18. Наріжний С. Українська еміграція. Культурна праця української еміграції між двома світовими війнами. Ч. І. Друге видання. Львів, Кент, Острог, 2008. 367 с.

19. Поштова картка Виконавчого комітету спілки товариств Червоного Хреста та Червоного Півмісяця СРСР від 3 квітня 1957 р. Архів УІТ (Архів Марка Антоновича). Ф. «Особові документи», 1 арк.

20. Рудницький Я. Із спогадів про Михайла Дмитровича Антоновича. Украӥнський історик. Т. 26. 1989. Ч. 4. C. $82-89$.

21. Тимощук В.Т. Історія в бетоні: Шкіц до життя історика Михайла Антоновича. Зона. 1998. № 13. С. 132 135.

22. Тимощук В.Т. Спогади про Михайла Антоновича. Украӥнський історичний журнал. 1998. № 3 (419). C. $142-144$.

23. Чубатий М. Рецензія на кн.: Д-р Михайло Антонович. Князь Рєпнін - генерал-губернатор Саксонії. Берлін, 1936. Український Науковий Інститут в Берліні, с. 1-61. Дзвони. Львів, 1937. Ч. 1/2. С. 61-62.

24. Шаповал А.І. Дмитро Антонович: життя та діяльність. Миронівка: ПРаТ «Миронівська друкарня», 2012. 348 c.

25. Шаповал А.І. Співпраця Михайла Антоновича з Українським історично-філологічним товариством у Празі. Архіви України. 2012. № 4 (280). С. 88-99. URL: http://nbuv.gov.ua/UJRN/ay_2012_4(280)_9 (дата звернення: 21.10.2019).

26. Яременко В.І. Історик Михайло Антонович за спогадами політв'язнів. Зона. 1998. № 13. С.126-131.

27. Яременко В.І. Історик Михайло Антонович у спогадах в'язнів сталінських таборів. Украӥнський історичний журнал. 1998. № 3 (419). С. 140-142.

28. Ясь О.В. Антонович Михайло Дмитрович. Енциклопедія історії України. Т. 1: (А-В). Київ: Наукова думка, 2003. С. 107-108.

29. Ohloblyn O. Ukrainian Historiography, 1917-1956. The Annals of the Ukrainian Academy of Arts and Sciences in the U.S. New York, 1957. Vol. V-VI. No. 4 (18). 1, 2 (19-20). P. 307-456.

\section{References}

1. Antonovych-Volf Raina. V pamiat Marka Antonovycha (oryhinal nimetskoiu movoiu). Arkhiv UIT (Arkhiv Marka Antonovycha). F. «Osobovi dokumenty». 2 ark.

2. Antonovych M. Istoriia Ukrainy. T. I: Kniazha doba. Praha: Vydavnytstvo Yuriia Tyshchenka, 1941. 80 s.

3. Antonovych M. Istoriia Ukrainy. T. II: Lytovsko-Ruska doba. Praha: Vydavnytstvo Yuriia Tyshchenka, 1941. $80 \mathrm{~s}$. 
4. Antonovych M. Istoriia Ukrainy. T. III: Kozachchyna ta Hetmanshchyna. Praha: Vydavnytstvo Yuriia Tyshchenka, 1941. $118 \mathrm{~s}$.

5. Antonovych M. Istoriia Ukrainy. T. IV: Nova doba. Praha: Vydavnytstvo Yuriia Tyshchenka, 1942. 89 s.

6. Antonovych M. Studii z chasiv Nalyvaika. Praha: UFIT v Prazi, 1941. $81 \mathrm{~s}$.

7. Antonovych Mykhailo. Entsyklopediia Ukrainoznavstva / za red. V. Kubiiovycha. Slovnykova chastyna. T. 1. Paryzh, Niu-York: NTSh, «Molode zhyttia», 1955. S. 51.

8. Arkhiv UIT (Arkhiv Marka Antonovycha).

9. Barbon M. U Norylskomu kontstabori [pro prof. M. D. Antonovycha]. Ukrainskyi istorychnyi zhurnal. 1995. № 5 (404). S. 134-136.

10. Velykopolska U. Epistoliarii v osobovomu fondi Myrona Korduby (z lystiv M. Antonovycha do M. Korduby). Pamiatky: arkheohrafichnyi shchorichnyk / Derzhavnyi komitet arkhiviv Ukrainy; Ukrainskyi naukovo-doslidnyi instytut arkhivnoi spravy ta dokumentoznavstva. Kyiv, 2008. T. 8. C. 271-278. URL: http://hrushevsky.nbuv.gov. $\mathrm{ua} / \mathrm{cgi}$-bin/hrushevsky/person.exe? \&I21DBN=ELIB\&P21DBN=ELIB \&S21STN=1\&S21REF=10\&S21FMT $=\mathrm{el}$ ib all $\& C 21 \mathrm{COM}=\mathrm{S} \& \mathrm{~S} 21 \mathrm{CNR}=20 \& \mathrm{~S} 21 \mathrm{P} 01=0 \& \mathrm{~S} 21 \mathrm{P} 02=0 \& \mathrm{~S} 21 \mathrm{P} 03=\mathrm{ID}=\& \mathrm{~S} 21 \mathrm{STR}=0001882 \quad$ (data zvernennia 18.10.2019).

11. Kivshar T. I. Avtobiohrafiia Mykhaila Antonovycha yak skladova yoho naukovoi biohrafii. Ukrainska biohrafistyka. 2008. Vyp. 4. S. 137-153. URL: http://nbuv. gov. ua/UJRN/ubi 2008410 (data zvernennia 20.10.2019).

12. Krupnytskyi B. Istorioznavchi problemy istorii Ukrainy (zbirnyk stattei). Miūunkhen: UVU, 1959. $228 \mathrm{~s}$.

13. Lyst Marka Antonovycha do Lubomyra Wynara vid 12 hrudnia 1985 r. z Monrealiu. Arkhiv UIT (Arkhiv L.Wynara). F. «Lystuvannia». Spr. «M. Antonovych». 1 ark.

14. Lyst Marka Antonovycha do Rainy Antonovych (Wolf) (Raina Wolff) vid 1 sichnia 1985 r. z Monrealiu v Tiubinhen. Arkhiv UIT (Arkhiv Marka Antonovycha). F. «Lystuvannia». 1 ark.

15. Lyst Mykhaila Antonovycha do Vasylia Yukhymovycha (Shymka) vid 23 liutoho 1944 r. z Breslau. Arkhiv UIT (Arkhiv Marka Antonovycha). F. «Lystuvannia». Spr. «Mykhailo Antonovych». 3 ark.

16. Lysty Mykhaila Antonovycha do Oleksandra Ohloblyna (1942-1943 rr.) Arkhiv UIT (Arkhiv Marka Antonovycha). F. «Lystuvannia». Spr. «Mykhailo Antonovych». 47 ark.

17. Mykola Barbon: «Tajno Antonovicha privezli na sever Francii. Noch'ju v portu peredali na bort sovetskogo torgovogo parahoda v ruki pereodetyh chekistov». URL: https://web. archive. org/web/20120310014709/http://www. memorial. krsk. ru/memuar/Kasabova/08/05. htm (data zvernennia: 21.10.2019).

18. Narizhnyi S. Ukrainska emihratsiia. Kulturna pratsia ukrainskoi emihratsii mizh dvoma svitovymy viinamy. Ch. I. Druhe vydannia. Lviv, Kent, Ostroh, 2008. 367 s.

19. Poshtova kartka Vykonavchoho komitetu spilky tovarystv Chervonoho Khresta ta Chervonoho Pivmisiatsia SRSR vid 3 kvitnia 1957 r. Arkhiv UIT (Arkhiv Marka Antonovycha). F. «Osobovi dokumenty», 1 ark.

20. Rudnytskyi Ya. Iz spohadiv pro Mykhaila Dmytrovycha Antonovycha. Ukrainskyi istoryk. T. 26. 1989. Ch. 4. S. $82-89$

21. Tymoshchuk V.T. Istoriia v betoni: Shkits do zhyttia istoryka Mykhaila Antonovycha. Zona. 1998. № 13. S. $132-135$.

22. Tymoshchuk V.T. Spohady pro Mykhaila Antonovycha. Ukrainskyi istorychnyi zhurnal. 1998. № 3 (419). S. $142-144$.

23. Chubatyi M. Retsenziia na kn.: D-r Mykhailo Antonovych. Kniaz Riepnin - heneral-hubernator Saksonii. Berlin, 1936. Ukrainskyi Naukovyi Instytut v Berlini, s. 1-61. Dzvony. Lviv, 1937. Ch. 1/2. S. 61-62.

24. Shapoval A.I. Dmytro Antonovych: zhyttia ta diialnist. Myronivka: PRaT «Myronivska drukarnia», $2012.348 \mathrm{~s}$.

25. Shapoval A.I. Spivpratsia Mykhaila Antonovycha z Ukrainskym istorychno-filolohichnym tovarystvom u Prazi. Arkhivy Ukrainy. 2012. № 4 (280). S. 88-99. URL: http://nbuv.gov.ua/UJRN/ay_2012_4(280)_9 (data zvernennia: 21. 10. 2019).

26. Iaremenko V.I. Istoryk Mykhailo Antonovych za spohadamy politviazniv. Zona. 1998. № 13. S.126-131.

27. Iaremenko V.I. Istoryk Mykhailo Antonovych u spohadakh viazniv stalinskykh taboriv. Ukrainskyi istorychnyi zhurnal. 1998. № 3 (419). S. 140-142.

28. Ias O.V. Antonovych Mykhailo Dmytrovych. Entsyklopediia istorii Ukrainy. T. 1: (A-V). Kyiv: Naukova dumka, 2003. S. 107-108.

29. Ohloblyn O. Ukrainian Historiography, 1917-1956. The Annals of the Ukrainian Academy of Arts and Sciences in the U.S. New York, 1957. Vol. V-VI. No. 4 (18). 1, 2 (19-20). P. 307-456. 